\title{
Antibacterial Activity and Phytochemical Analysis of Methanolic and Acetonic Extracts from Moringa oleifera, Vitex negundo and Rosa indica
}

\author{
Kruti Dave ${ }^{1}$, Hardik Shah ${ }^{2}$ and Kirankumar G. Patel ${ }^{3 *}$ \\ ${ }^{1}$ Department of Biotechnology, ${ }^{2}$ Department of Microbiology, Mehsana Urban Institute of \\ Sciences, Ganpat University, Gujarat, India \\ ${ }^{3}$ Department of Biological Sciences, P. D. Patel Institute of Applied Sciences, CHARUSAT, \\ Gujarat, India
}

*Corresponding author

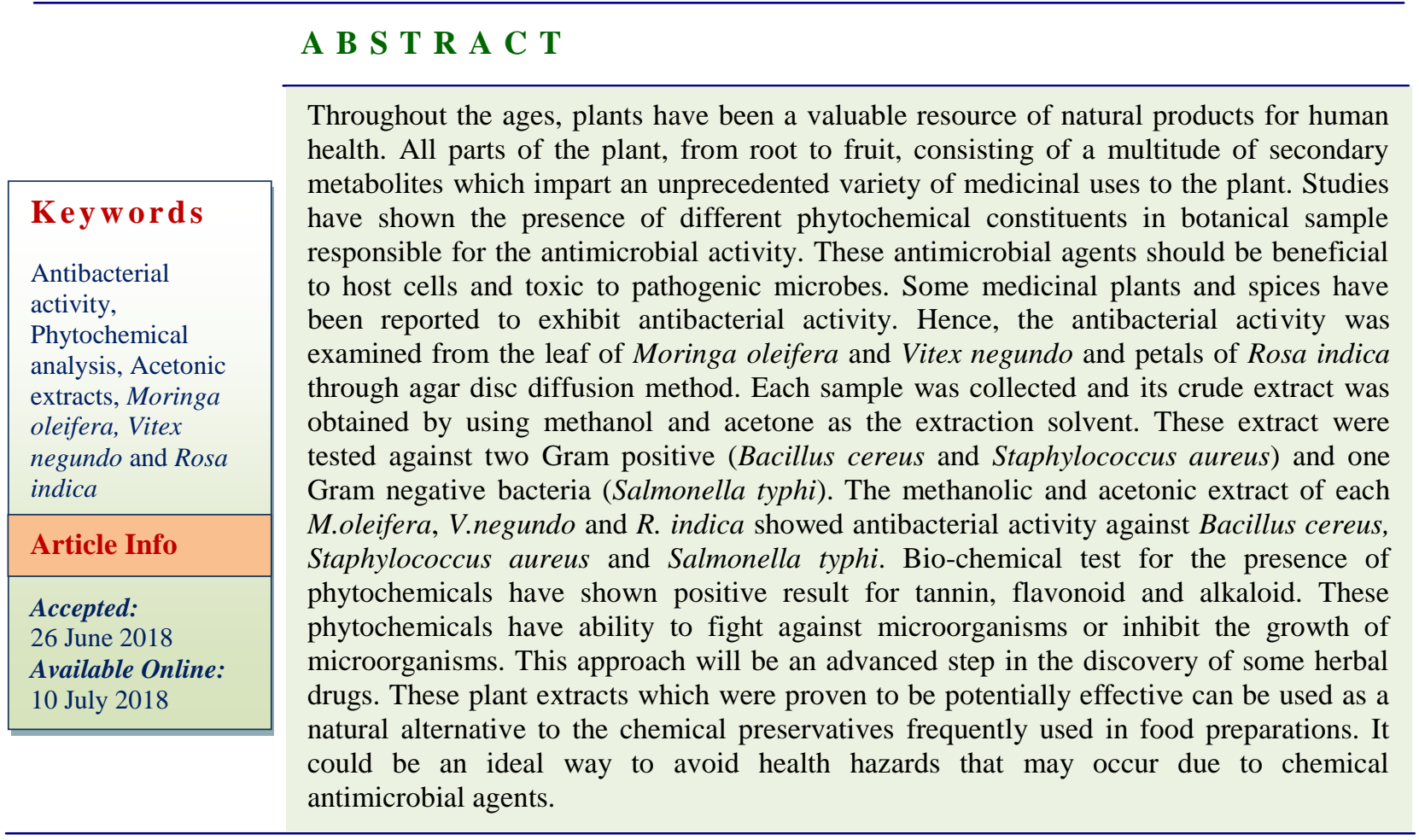

\section{Introduction}

Microbes are present everywhere in the biosphere and they have both, beneficial or harmful effects with regard to human measure or surveillance. The major harmful effect is food poisoning due to bacterial contamination which causes illness and death in developing countries (Doughari, 2012). Particularly members of Gram negative bacteria such as 
Salmonella typhi, Escherichia coli and Pseudomonas aeruginosa; and Gram positive bacteria such as Bacillus cereus, Bacillus subtilis and Staphylococcus aureus; have been identified as causal agents of food spoilage or food borne diseases (Mostafa et al., 2018; Ibrahim and Fagbohun 2013;Lucera et al., 2012).

Antibiotics and chemical preservatives are boon for the control of food poisoning diseases since they are one of the most important weapons to fight against bacterial infections. Their benefits are numerous but over last few years, utilization of chemical preservatives and antibiotics handled to various consequences such as microbial resistance, accumulation of chemical residues in feed and food chain and undesirable side effects (such as nausea, depression of bone marrow, thrombocytopenic purpura and agranulocytosis) on human health (Fair and Tor, 2014; Bialonska et al., 2010). Hence, new efforts and effective techniques are required in order to fight against these problems.

Plants are a very good source of medicinal compounds that play a vital role in human health as they represent a rich source of phytochemical constituent (Mostafa et al., 2018). These phytochemical includes the range of secondary metabolites such as alkaloids, terpenoids, tannins, flavonoids and glycosides, etc., which have a different antimicrobial properties (Doughari, 2012). Various extract from the parts of the plant like root, stem, leaf, fruit and flower have been experimentally shown to have anti-microbial activity and also regarded as nutritionally safe and easily degradable. Hence, the extract of various species of edible and medicinal plants, can be used as the substitute source of synthetic antimicrobials for preservation in food and beverages, and it also offersa great significance in the therapeutic treatments (Hintz et al., 2015; Mbakwem-Aniebo et al., 2017). However, this phytochemical based approach is not much developed compared to the modern system of medicine, due to either lack of or insufficient scientific studies in this area.

Several researchers have demonstrated antimicrobial activity against pathogenic bacteria from the extracts of various plants such as guava, garlic, ginger, cumin, clove, pomegranate etc. (Mostafa et al., 2018; Nuamsetti et al., 2012; Maharjan et al., 2011). In the same line of work, Moringa oleifera (drumstick tree),Vitexnegundo (five-leaved chaste tree) and Rosa indica(rose) were used in the present study.

M. oleifera has been used as traditional medicine for the treatment of several skin diseases; as stimulant in paralytic afflictions, epilepsy and hysteria. The root of this plant is reported to exhibit anti-inflammatory action while its other parts such as leaves, stem and seeds also had demonstrated various therapeutic properties (Kalpana et al., 2013; Dalukdeniya et al., 2016).

$V$. negundo is a medicinally important plant reported for beneficial properties like antiinflammatory, anti-asthmatic, antibacterial and antifungal (Rose and Catherine, 2011; Srinivas et al., 2010;Gautam and Kumar, 2012). Rosa indica is generally most popular for its beauty, fragrance and antimicrobial as well as antioxidant properties (Halawani et al., 2014; Kumar et al., 2012).

Thus, for extending the understanding about phytochemical properties of $M$. oleifera, $V$. negundo and $R$. indica, the present study was aimed at two main objectives.

First, to assess the antibacterial activity of plant extract (methanol, ethanol and acetone) against gram positive and gram negative bacteria by disc diffusion method and second, to evaluate phytochemical nature of plant extract. 


\section{Materials and Methods}

\section{Plant materials and bacterial strain}

Leaves of $M$. oleifera and $V$. negundo; and petals of $R$. indica were used as plant material for preparation of extract. The antibacterial activity of each plant extract was assessed using three bacterial strains causing food poisoning diseases, two strains of Gram positive (Staphylococcus aureus and Bacillus cereus) and one strains of Gram negative (Salmonella typhi) bacteria.

\section{Preparation of plant extracts}

The plant materials, from M. oleifera, $V$. negundo and $R$. indica were collected, disinfected, water washed, and dried under a shade. The dried plant material of each plant species was grind using mortar and pestle to obtain fine powder and then was passed through $1.00 \mathrm{~mm}$ sieve. 20 gram fine powder of each plant was soaked in $100 \mathrm{ml}$ of different solvents such as methanol and acetone separately for 48 hours followed by loading in soxhlet apparatus and subject to continuous extraction (4-5 hours) with respective solvents to obtain crude extracts. There after the solvent (acetone or methanol) was removed under reduced pressure using rotatory vacuum evaporator (Wang and Weller 2006; Maharjan et al., 2011). The concentrated residues were dissolved in dimethyl sulphoxide (DMSO; 10\%w/v) and stored at $4^{\circ} \mathrm{C}$ until use (Kalpana et al., 2013). The extract yields were weighted and stored in small bottles in refrigerator at $4^{\circ} \mathrm{C}$. Yield percentages were calculated using the following formula:

Extract yield $\%=\mathrm{R} / \mathrm{S} \times 100$

Where $\mathrm{R}$ = weight of extracted plants residues and $\mathrm{S}=$ weight of raw plant sample.
Evaluation of antimicrobial activities of plant extracts

Antimicrobial activity of plant extracts was analysed by disc diffusion method as described by Bauer et al., (1966) and Cakir et al., (2004) with minor modification. About $20 \mathrm{ml}$ nutrient (base) agar was plated in petri dishes and allowed to solidify for 30 minutes. The test microorganisms such as Bacillus cereus, Staphylococcus aureus and Salmonella typhi were seeded $\left(0.2 \mathrm{ml}: 10^{7}-10^{8}\right.$ cells $\left./ \mathrm{ml}\right)$ into sterile molten nutrient soft agar medium which was overlaid on the nutrient agar base. The filter discs (5 $\mathrm{mm}$ diameter) were soaked with extracts $(100 \mathrm{mg} / \mathrm{ml})$ and then placed on the surface of the seeded agar plates. A filter disc saturated with $10 \mu$ l of DMSO (Dimethyl sulphoxide) was used as negative control. These plates were incubated at $37^{\circ} \mathrm{C}$ for $24-48$ hours to allow maximum growth of the microorganism. After incubation, the plates were observed for clear, distinct zone of inhibition surrounding the disc. The diameter $(\mathrm{mm})$ of zone of inhibition produced by the extract was measured and compared with the standard. All assays performed in triplicates to consider mean values as a standard one.

\section{Phytochemical analysis of plant extract: Test for Tannins}

About $1 \mathrm{ml}$ extract (Conc. 10\%w/v) was mixed in $3 \mathrm{ml}$ water and heated on boiling water for 5 minutes and then filtered. Further, $1 \mathrm{ml}$ of $0.1 \%$ ferric chloride was addedto $3 \mathrm{ml}$ filtrate and observed for the appearance of dark green color or blue- black color. The appearance of this color indicates the presence of tannins (Edeoga et al., 2005).

\section{Test for flavonoids}

The different plant extracts $(0.5 \mathrm{ml})$ was shaken with petroleum ether to remove the fatty materials (lipid layer). The defatted 
residue was dissolved in $20 \mathrm{ml}$ of ethanol and filtered. $3 \mathrm{ml}$ of the filtrate was mixed with 4 $\mathrm{ml}$ of $1 \%$ potassium hydroxide in a test tube and the color change was observed. A dark yellow color indicates the presence of flavonoids (Hadi and Bremner 2001).

\section{Test for alkaloids}

Wagner's test and Mayer's test were performed to study the presence of alkaloids. $0.5 \mathrm{ml}$ of extract was mixed and with $8 \mathrm{ml}$ of 1 $\% \mathrm{HCl}$ followed by heating in boiling water bath. After cooling, the mixture was filtered. Thereafter $2 \mathrm{ml}$ of the filtrate treated with Mayer's and Wagner's reagents, and observed for the formation of white-yellowish and reddish- brown precipitate respectively (Evans 1997; Wagner 1984).

\section{Results and Discussion}

Now a day, immense and indiscriminate utilization of antibiotics for the treatment of infectious diseases is leading to the emergence of drug resistance among etiological agents similarly chemical preservatives are also employed to control food pathogens, but it is influenced by several factors such as high cost and severe side effects. Hence, it is an alarming situation and deserves major attention to develop other promising alternatives (Sharma, 2015; Silva and Lidon, 2016). Plants are the readily available resource of valuable natural therapeutic remedies and have a long history of healing effects and more over a promising alternative to chemical preservatives and medicine. Approximately 3000 plants species in India are known to have medicinal properties (Prakasha et al., 2010). These medicinal plants may prove to be rich source of compounds with possible antimicrobial properties but more antimicrobial and phytochemical investigation is necessary.
In the present study antibacterial activity and phytochemical properties of $M$. oleifera, $V$. negundo and $R$. indica, were investigated. Plant materials were dried and extracted using methanol and acetone to extract valuable compounds.

\section{Plants extraction yield}

The ethnobotanical data of the employed plants and their extract percentage yield are illustrated in Table 1. Plant materials with methanol yielded plant extract residues ranged from 24.35 to $9.83 \%$ while in case of acetone it ranged from 12.42 to $8.62 \%$.The higher extract yield in methanol may be due to the higher solubility of proteins, carbohydrates and other compounds in methanol compared to acetone (Do et al., 2014). The highest yield of plant extract was obtained from $M$. oleifera followed by $V$. negundo while $R$. indicagives the lowest extract yield.

\section{Phytochemical analysis of plant extract}

Phytochemical analysis of $M$. oleifera, $V$. negundo and $R$. indica revealed the presence of phenols, alkaloids, tannins, flavonoids and saponins (Table 1). Whereas xantho proteins were not detected in methanol and acetone extract of all these plants. Similarly, the presence of these phytochemicals has reported by many authors in plant extract of the same plants with various extraction solvents such as chloroform, ethanol, ethyl ether etc. (Bukar et al., 2010, Rose and Cathrine 2011, Gautam and kumar 2012 and Halawani et al., 2014). It is well documented that phytochemical such as phenols, alkaloids, tannins, flavonoids and saponins can act as an antimicrobial compound and play an important role to fight against microbes (Do et al., 2014). Hence these all plant extracts were further used for the analysis of antimicrobial activity against different bacteria by disc diffusion method. 
Table.1 The ethnobotanical data of employed plant species and their extract yield (\%)

\begin{tabular}{|l|c|c|c|c|c|}
\hline \multicolumn{1}{|c|}{ Plant spices } & Family & $\begin{array}{c}\text { Common } \\
\text { Name }\end{array}$ & $\begin{array}{c}\text { Plant part } \\
\text { used }\end{array}$ & \multicolumn{2}{|c|}{ Extraction yield (\%) } \\
\hline Moringa oleifera & Moringaceae & Drumstick & Leaf & 24.35 & 12.42 \\
\hline Vitex negundo & Verbenaceae & Nirgundi & Leaf & 16.67 & 10.90 \\
\hline Rosa indica & Rosaceae & Rose & Patals & 9.83 & 8.62 \\
\hline
\end{tabular}

Table.2 Phytochemical constituent analysis of methanol and acetone extracts of $R$. indica, $V$. negundo and M.oleifera. Where $(+)=$ Present and $(-)=$ absent; High amount $=(+++)$; Relatively high $=(++)$, Trace amount $=(+)$

\begin{tabular}{|c|c|c|c|c|}
\hline \multirow{2}{*}{$\begin{array}{l}\text { Phyto- } \\
\text { constituent }\end{array}$} & \multirow{2}{*}{$\begin{array}{l}\text { Solvent } \\
\text { system }\end{array}$} & \multicolumn{3}{|c|}{ Plant extract } \\
\hline & & Moringa oleifera & Vitex negundo & Rosa indica \\
\hline \multirow{2}{*}{$\begin{array}{l}\text { Phenolic } \\
\text { compounds }\end{array}$} & Methanol & ++ & +++ & +++ \\
\hline & Acetone & + & ++ & ++ \\
\hline \multirow[t]{2}{*}{ Alkaloids } & Methanol & ++ & ++ & +++ \\
\hline & Acetone & + & + & ++ \\
\hline \multirow[t]{2}{*}{ Tannins } & Methanol & ++ & +++ & ++ \\
\hline & Acetone & + & ++ & + \\
\hline \multirow[t]{2}{*}{ Flavonoids } & Methanol & ++ & +++ & ++ \\
\hline & Acetone & + & ++ & + \\
\hline \multirow[t]{2}{*}{ Xantho proteins } & Methanol & - & - & - \\
\hline & Acetone & - & - & - \\
\hline \multirow[t]{2}{*}{ Saponins } & Methanol & + & ++ & - \\
\hline & Acetone & + & + & - \\
\hline
\end{tabular}


Table.3 Determination of antimicrobial activity of $V$. Negundo, $R$. indica and $M$. oleifera against bacterial pathogens by disc diffusion method. Values represented as mean \pm SE (standard error)

\begin{tabular}{|c|c|c|c|}
\hline \multirow{2}{*}{$\begin{array}{c}\text { Plant } \\
\text { sample }\end{array}$} & \multirow[t]{2}{*}{ Microorganism } & \multicolumn{2}{|c|}{ Zone of inhibition (mm) } \\
\hline & & Methanol & Acetone \\
\hline \multirow[t]{3}{*}{ M. oleifera } & B. cereus & $17.83 \pm 0.44$ & $14.33 \pm 0.88$ \\
\hline & S. aureus & $13.17 \pm 0.60$ & $10.50 \pm 0.29$ \\
\hline & S. typhi & $9.67 \pm 0.66$ & $6.83 \pm 0.17$ \\
\hline \multirow[t]{3}{*}{ V. negundo } & B. cereus & $15.00 \pm 0.76$ & $9.00 \pm 0.76$ \\
\hline & S. aureus & $10.33 \pm 0.33$ & $7.00 \pm 0.29$ \\
\hline & S. typhi & $6.17 \pm 0.44$ & $5.80 \pm 0.16$ \\
\hline \multirow[t]{3}{*}{ R. indica } & B. cereus & $16.00 \pm 1.00$ & $14.00 \pm 0.58$ \\
\hline & S. aureus & $9.17 \pm 0.17$ & $7.33 \pm 0.37$ \\
\hline & S. typhi & $7.00 \pm 0.29$ & $5.83 \pm 0.16$ \\
\hline
\end{tabular}

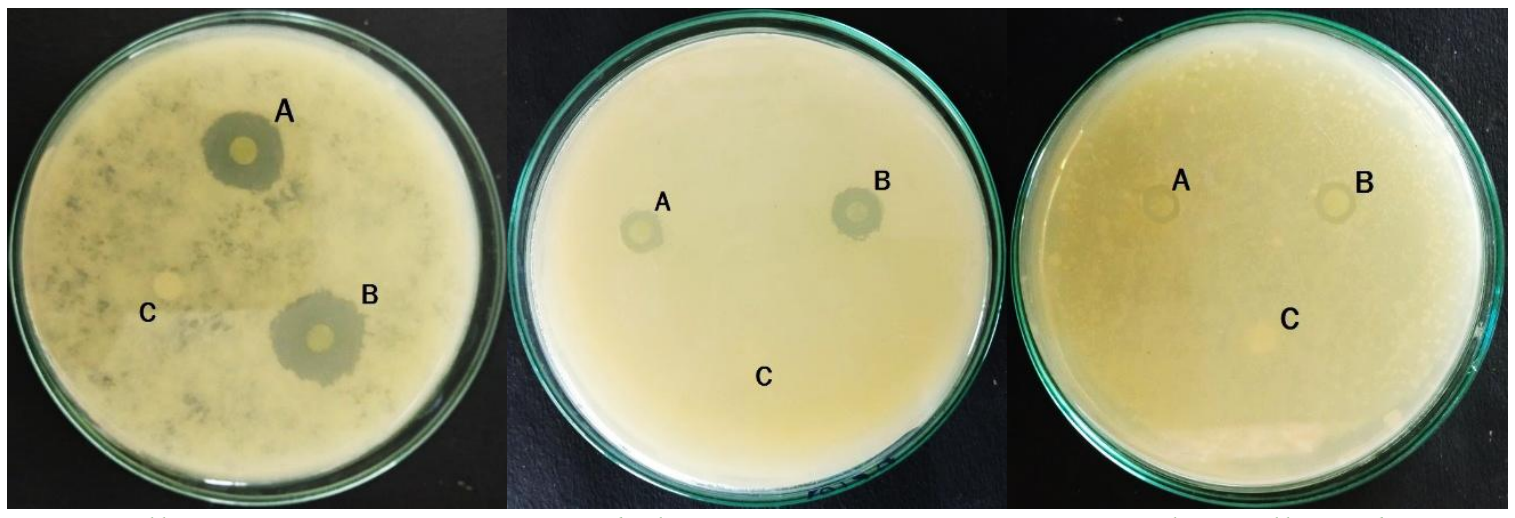

Bacillus cereus

Staphylococcus aureus

Salmonella typhi

Fig.1a - Effect of Moringa oleifera extracts on different bacteria.

A) Acetone extract B) Methanol extract C) Control 


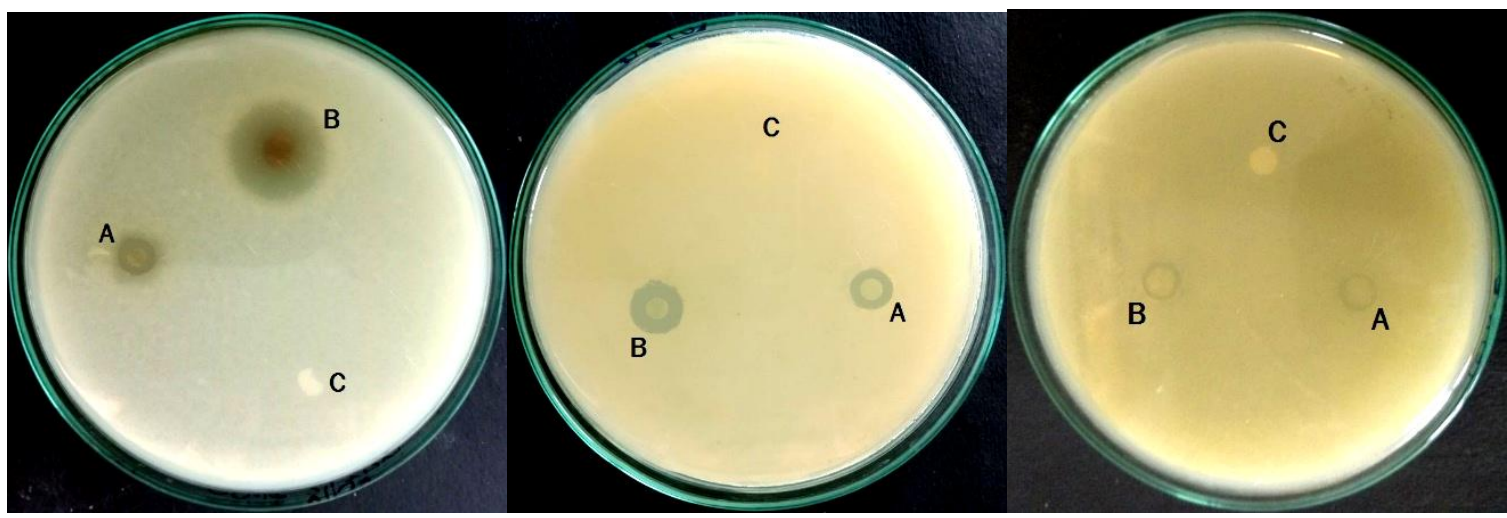

Bacillus cereus

Staphylococcus aureus

Salmonella typhi

Fig.1b - Effect of Vitex negundo extracts on different bacteria.

A) Acetone extract B) Methanol extract C) Control

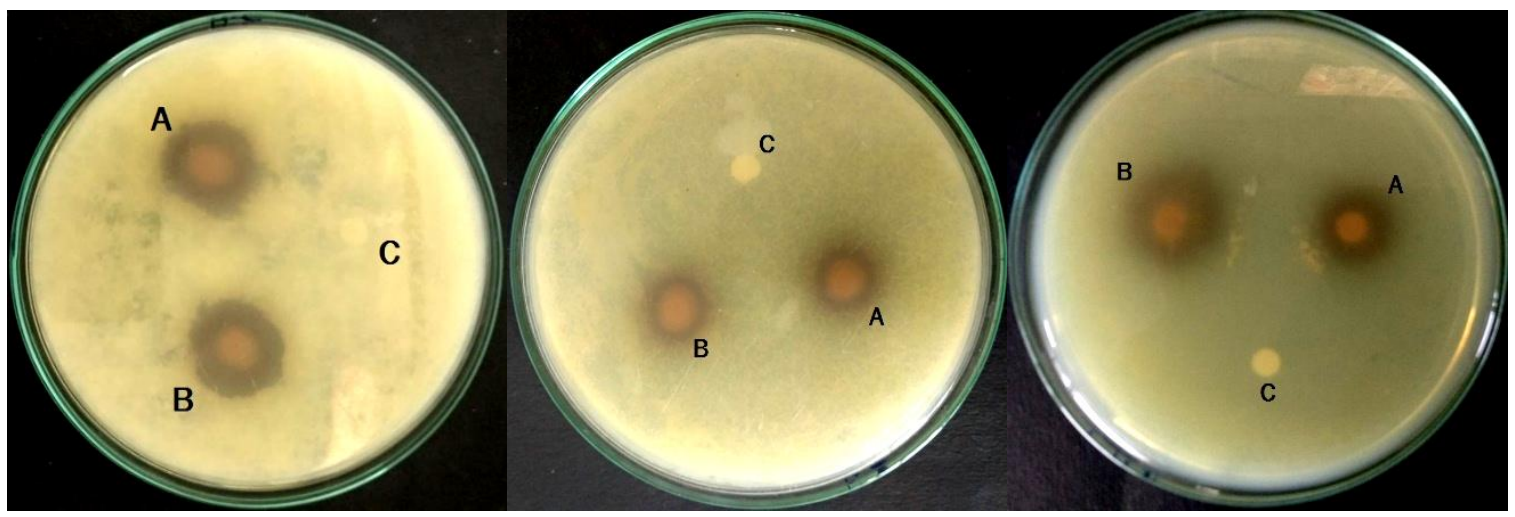

Bacillus cereus

Staphylococcus aureus

Salmonella typhi

Fig.1c - Effect of Rosa indica extracts on different bacteria.

A) Acetone extract B) Methanol extract C) Control

Fig.2 Comparison of methanolic and acetonic extract of $M$. oleifera and $V$. negundo, $R$. indica against bacterial pathogens. Graph represents the mean \pm SE $(n=3)$ followed by similar lower case letter are significantly not different according to Tukey's multiple range at $\mathrm{P} \leq 0.05$

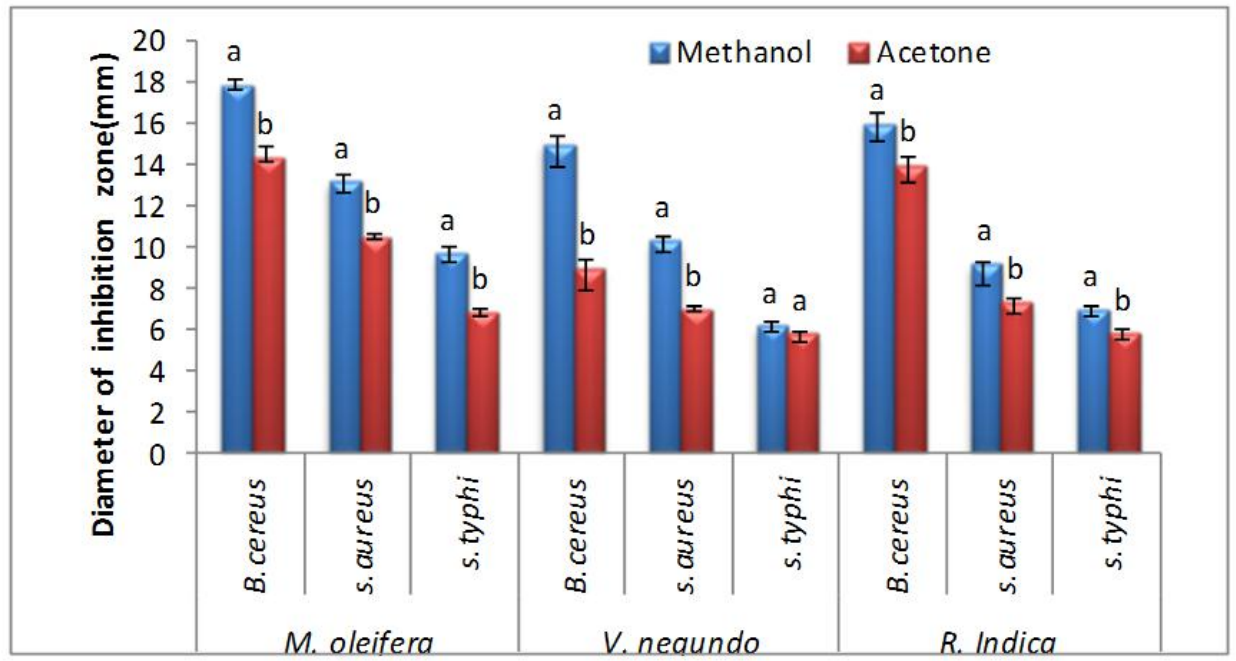


The extracts from $M$. oleifera, $R$. indica and $V$. negundo showed varying degrees of antimicrobial activity against the different test organisms (Table 3) while there was no inhibition of growth with the control (DMSO) as it used as negative control (Fig. 1). Methanolic and acetonic extract from $M$. oleifera showed higher zone of inhibition against different test organisms in a rage of $17.83-9.67 \mathrm{~mm}$ and $14.33-6.83 \mathrm{~mm}$ respectively (Table 3; Fig. 2). Similarly $R$. indica and $V$. negundo also exhibited antimicrobial activity against different test organisms. Overall, it was observed that methanolic extract exhibited significant higher $(\mathrm{p} \leq 0.05)$ antibacterial activity against all test organisms as compared to acetonic extract (except in case of $V$. negundo against S. typhi). All three plants extracts (methanolic and acetonic) showed comparative elevated antimicrobial activity against $B$. cereus followed by $S$. aureus and $S$. typhi. Methanolic extract from $M$. oleifera showed $24 \%, 25 \%$ and $41 \%$ higher activity against $B$. cereus, $S$. aureus and $S$. typhi compared to acetonic extract respectively (Fig. 2).

Similarly, elevated antimicrobial activity in methanolic extract was reported in M.oleifera (Kalpana et al., 2013), Phyllanthus niruri (Shanmugam et al., 2014), Simmondsia chinensis, Jatropha curcas, Zingiber officinale and Syzygium aromaticum (Ibrahim and Abu-Salem 2014) compared to aqueous extract. In addition, extract yield in methanol solvent was significantly higher; therefore it may enhance the solubility of active components of $M$. oleifera, $R$. indica and $V$. negundo which resulted in higher antimicrobial activity compared to acetone extract. Results of antimicrobial activity of the three plant extracts suggested that $S$. typhi was more resistant strain to plant extracts as compared to B. cereus and $S$. aureus. As $S$. typhi contains an outer lipopolysaccharide layer, it may hinder the access of most components to the peptidoglycan layer of cell wall (Srinivas et al., 2010). This could be the possible reason for lower activity of different plant extracts against $S$. typhi.

In conclusion, this study reports the presence of various phytochemical constituents such as alkaloids, tannins and phenolic compound in different solvent extracts (methanol, acetone) of $V$. negundo, $R$. indica and $M$. oleifera. Among both extraction solvents methanol gives higher extraction yield for all three plants. Methanolic and acetonic extract from these plants offered a significant antimicrobial activity to test organism show ever methanolic extract from these plants showed comparative higher antimicrobial activity. In addition to this study further efforts including quantification, purification, detection of toxicity and side effects of antimicrobial compounds, may be required to strengthen potential this antimicrobial plant extract and favourable outcomes.

\section{Acknowledgment}

Authors would like to thank Mehsana Urban Institute of Sciences, Ganpat University, Gujarat, India, for providing facilities to carry out this research work.

\section{References}

Bauer, A.W., Kirby, W.M., Sherris, J.C. and Turck, M., 1966. Antibiotic susceptibility testing by a standardized single disk method. American journal of clinical pathology, 45(4):493-496.

Bialonska, D., Ramnani, P., Kasimsetty, S.G., Muntha, K.R., Gibson, G.R. and Ferreira, D., 2010. The influence of pomegranate by-product and punicalagins on selected groups of human intestinal microbiota. International journal of food microbiology, 140(2-3):175-182. 
Bukar, A., Uba, A. and Oyeyi, T., 2010. Antimicrobial profile of Moringa oleifera Lam. extracts against some food-borne microorganisms. Bayero Journal of Pure and Applied Sciences, 3(1): 43 - 48.

Cakir, A., S. Kordali, H. Zengin, S. Izumi and Hirata, T. 2004. Composition and antifungal activity of essential oils isolated from Hypericumhus sopifolium and $H$. heterrophyllum. Flavour Frag. J. 19:62-68.

Dalukdeniya, D.A.C.K., De Silva, K.L.S.R. and Rathnayaka, R.M.U.S.K., 2016. Antimicrobial Activity of Different Extracts of Leaves Bark and Roots of Moringa oleifera (Lam). Int. J. Curr. Microbiol. App. Sci, 5(7):687-691.

Do, Q.D., Angkawijaya, A.E., Tran-Nguyen, P.L., Huynh, L.H., Soetaredjo, F.E., Ismadji, S. and Ju, Y.H., 2014.Effect of extraction solvent on total phenol content, total flavonoid content, and antioxidant activity of Limnophila aromatica. Journal of food and drug analysis, 22(3):296-302.

Doughari, J.H., 2012. Phytochemicals: Extraction methods, basic structures and mode of action as potential chemotherapeutic agents. In Phytochemicals-A global perspective of their role in nutrition and health.InTech.

Edeoga, H.O., Okwu, D.E. and Mbaebie, B.O., $2005 . \quad$ Phytochemical constituents of some Nigerian medicinal plants. African journal of biotechnology, 4(7):685-688.

Evans, W.C.,1997. An index of medicinal plants. In: $A$ Text book of Pharmacognosy, 14 ed. 7(5): 12-14.

Fair, R.J. and Tor, Y., 2014.Antibiotics and bacterial resistance in the 21 st century. Perspectives in medicinal chemistry, 2014(6):25-64.

Gautam, K. and Kumar, P., 2012. Extraction and pharmacological evaluation of some extracts of Vitexnegundo Linn.Int J Pharm PharmSci, 4(2):132137.

Hadi, S., and Bremner.J.B., 2001.Initial studies on Alkaloids from Lombok Medicinal Plants.Molecules, 6:117129.

Halawani, E.M., 2014. Antimicrobial activity of Rosa damascena petals extracts and chemical composition by gas chromatography-mass spectrometry (GC/MS) analysis. African Journal of Microbiology Research, 8(24):23592367.

Hintz, T., Matthews, K.K. and Di, R., 2015.The use of plant antimicrobial compounds for food preservation. BioMed research international, 2015:1-12.

Ibrahim, H., and Abu-Salem, F. 2014. Antibacterial Activity of Some Medicinal Plant Extracts. International Journal of Biological, Biomolecular, Agricultural, Food and Biotechnological Engineering. 8(10):1168-1173.

Ibrahim, T.A. and Fagbonun, E.D., 2013. Antibacterial and antifungal activity of ethanolic and methanolic extract of dried Seeds of Buchhlozia coriacea. Greener Journal of Agricultural Sciences, 3(6):458-463.

Kalpana, S., Moorthi, S. and Kumara, S., 2013. Antimicrobial activity of different extracts of leaf of Moringaoleifera (Lam) against gram positive and gram negative bacteria. International Journal of Current Microbiology and Applied Sciences, 2(12):514-518.

Kumar, U., Kumar, K. and Hindumathy, C.K., 2012. Study of Antimicrobial Activity of Rosa indica against Gram Positive and Gram Negative Microorganisms. International Journal of Microbiology 
Research, 4(3):186-189.

Lucera, A., Del Nobile, M.A., Costa, C. and Conte, A., 2012. Food applications of natural antimicrobial compounds. Frontiers in Microbiology, 3(287):113.

Maharjan, D., Singh, A., Lekhak, B., Basnyat, S. and Gautam, L.S., 2011. Study on antibacterial activity of common spices. Nepal Journal of Science and Technology, 12(20):312-317.

Mbakwem-Aniebo, C., Osadebe, A.U. and Obi, S.E., 2017.Phytochemical Screening and Evaluation of the Effects of Methanolic and Ethanolic Extracts of Jatrophacurcas and Chlorophoraexcelsa on Candida albicans and Staphylococcus aureus.Int. J. Curr. Microbiol. App. Sci, 6(5):1883-1888.

Mostafa, A.A., Al-Askar, A.A., Almaary, K.S., Dawoud, T.M., Sholkamy, E.N. and Bakri, M.M., 2018. Antimicrobial activity of some plant extracts against bacterial strains causing food poisoning diseases. Saudi Journal of Biological Sciences, 25(2): 361-366.

Nuamsetti, T., Dechayuenyong, P. and Tantipaibulvut, S., 2012. Antibacterial activity of pomegranate fruit peels and arils.Science Asia, 38(3):319-22.

Prakasha, H.M., Krishnappa, M., Krishnamurthy, Y.L. and Poornima, S.V., 2010.Folk medicine of NR Purataluk in Chikmagalur district of Karnataka. Indian Journal of Traditional Knowledge, 9(1): 55-60.
Rose, M. C. and Cathrine, L., 2011.Preliminary phytochemical screening and antibacterial activity on Vitex negundo. Intern. J. Current Pharm. Res, 3:99-101.

Shanmugam, B., Shanmugam, K.R., Ravi, S., Subbaiah, G.V., Mallikarjuna, K. and Reddy, K.S., 2014. Antibacterial activity and phytochemical screening of Phyllanthusniruri in ethanolic, methanolic and aqueous extracts.Int $J$ Pharm SciRev \& Res, 27(2):85-89.

Sharma, S., 2015.Food Preservatives and their harmful effects.International Journal of Scientific and Research Publications, 5(4): 1-2.

Silva, M.M. and Lidon, F.C., 2016.Food preservatives - An overview on applications and side effects.Emirates Journal of Food and Agriculture. 28(6): 366-373.

Srinivas, P., Reddy, S.R., Pallavi, P., Suresh, A. and Praveen, V., 2010.Screening for antimicrobial properties of Vitex negundo $\mathrm{L}$ from rural areas of Warangal Dist/AP India.International Journal of Pharma and Bio Sciences, 1(4):26-38.

Wagner, H., Bladt, S. and Zgainski, M., 1984. Plant Drug Analysis, Springer, Berlin, 260-261.

Wang, L. and Weller, C.L., 2006. Recent advances in extraction of nutraceuticals from plants. Trends in Food Science \& Technology, 17(6):300-312.

\section{How to cite this article:}

Kruti Dave, Hardik Shah and Kirankumar G. Patel. 2018. Antibacterial Activity and Phytochemical Analysis of Methanolic and Acetonic Extracts from Moringa oleifera, Vitex negundo and Rosa indica. Int.J.Curr.Microbiol.App.Sci. 7(07): 3718-3727.

doi: https://doi.org/10.20546/ijcmas.2018.707.430 